\title{
IMPLEMENTATION OF TRANSDISCIPLINARY APPROACH IN THE PROCESS OF FORMATION OF FUTURE PRIMARY SCHOOL TEACHERS' COMMUNICATIVE-STRATEGIC COMPETENCE
}

\author{
MARIIA OLIIAR, KATERYNA FOMIN
}

\begin{abstract}
The urgency of the problem of formation of communicative-strategic competence of future primary school teachers is substantiated in the article. The importance of implementing a communicative approach in the professional training of students in terms of reforming the education system in accordance with the Concept of the New Ukrainian School is emphasized. The authors of the article emphasized the specifics of pedagogical discourse as strategically planned and aimed at achieving a certain communicative goal. The results of the survey of graduate students majoring in "Primary Education" are revealed, which proved the necessity of developing a special methodology for the formation of future teachers' communicative-strategic competence. The essence of the transdisciplinary approach as the basis of the specified technique is revealed. The characteristics, basics and the overarching purpose of the method are given. It is substantiated that in the conditions of the organization of pedagogical discourse the purpose becomes a process of educational work, ways and methods of knowledge acquiring and mastering of skills in the specific intersubjective communicative-dialogic space created by the teacher which students join as equal participants of communication among other participants with common considering of social situation, specifics of the future profession, professional language. The communicative concepts of navigation character are defined and conceptual fields of interconnected communicative concepts for providing transdisciplinary connections are characterized. The principles of realization of the offered technique are revealed: conformity of the modeled educational process to the final purpose of future teachers' training for work in the conditions of the communicative environment of modern primary school; taking into account specifics of future professional activity; considering psychological features of future teachers' acquisition of communicative knowledge and skills; optimal combination of theoretical knowledge and practical skills; selection of the most effective forms, methods, technologies of formation of communicative-strategic competence.
\end{abstract}

Keywords: future primary school teacher, pedagogical discourse, communicative strategy, communicative tactics, communicative-strategic competence, transdisciplinarity, conceptual field of communicative concepts, transdisciplinary methodology.

\section{INTRODUCTION}

In the context of the implementation of the Concept of the New Ukrainian School - "a document that proclaims the preservation of childhood values, the need for humanization of learning, personal approach, development of students' abilities, creating a learning environment that provides children' psychological comfort and creativity" [11, p. 2] - the problem of formation of schoolchildren's communicative competence acquires new value on the basis of dialogue - interaction - mutual respect. 
Implementation of new tasks of primary school: to train students for life in a modern dynamic information society, to cultivate their ability for continuous self-education and self-development [14] is impossible without proper mastery of communication skills. This actualizes the problem of training future teachers for interpersonal communication in school, the implementation of a communicative approach in the professional training of students. It is no coincidence that modern scholars consider language strategies a factor of educational innovation, creation of environmentally friendly integrated multilingual space both at and out of school in accordance with modern challenges [1].

\section{ANALYSIS AND DisCUSSION}

The problem of development of the communicative sphere of future specialists in any field is relevant today in all countries of the world. The modern conception of the problem was formed in the second half of the twentieth century and covered the fields of philosophy, linguistics, sociolinguistics, linguodidactics, psycholinguistics, pedagogical theory and practice, psychology, and others. Various aspects related to the field of education have been researched by both domestic and foreign scientists, in particular: N. Babych, V. Bader, M. Vashulenko, A. Gabidullina, A. Dobrovych, O. Issers, V. KanKalyk, S. Karaman, V. Karasyk, O. Lyubashenko, L. Mamchur, L. Palamar, M. Pentylyuk, L. Petrovska, Y. Romanenko, etc.). Researchers emphasize the growing role of strategic planning in various areas of communication [10]. This is evidence that communicative issues, including the formation of a strategic component of pedagogical communication, has a complex nature and long-term evolution.

The concepts of "strategy" and "tactics" are defined in the "Oxford Advanced Learner Dictionary of Current English" as follows: strategy - "a plan that is intended to achieve a particular purpose"; tactics - "the particular method you use to achieve something" [9, p. 1336, 1375]. Ukrainian researcher Y. Romanenko characterized communicative strategy as a dynamic, variable cognitive-speech program for the implementation of all types of speech activity [12, p. 214].

Modern scientific research proves that communication is an integral part of the educational process, an important didactic resource. O. Lyubashenko established categorical characteristics of linguodidactic strategy, its structure, position in the system of didactic categories [8]. Communication is considered productive if there is interaction, mutual understanding, development and improvement of personality [3]. Scientists emphasize that the lack of communication skills creates significant difficulties for students, especially at the stage of adaptation to school [2]. Strategic planning of pedagogical communication is an important component of educational process management, which allows students to master collective and individual forms of educational activities, to acquire new skills and abilities, to develop learning interest.

According to scientists, "language communication is a strategic process, the basis for which is the choice of optimal language resources. The transmission of messages in the communication process can be considered as a series of speaker's decisions. Most of them are made unconsciously, automatically. However, the specificity of pedagogical discourse is in many cases, not a spontaneous, but a clearly planned process aimed at achieving a predetermined communicative goal. Therefore, the development and implementation of methods for the formation of future teachers' communicative-strategic competence is an urgent task of professional training.

Future primary school teachers' communicative-strategic competence is considered as an integrative unity of the teacher's personal and professionally significant qualities, acquired in the process of specially organized training, which combines a system of values, motives, emotions, cognitive abilities, scientific and theoretical knowledge, practical skills, behavioral components aimed at adequate selection and implementation of familiar communication strategy tactics and building of new in planned or unforeseen situations of professional communication in order to implement successful pedagogical interaction in the communicative environment of primary school.

To diagnose communicative and strategic competence, 100 graduate students majoring in "Primary Education" were asked to answer the following questions of the questionnaire:

1. What is a communication strategy? 
2. What qualities of the teacher's communicative personality can you name?

3. Do you plan in advance the way you will communicate with students in class?

4. Do you have difficulties communicating with primary school students?

5. Do you always analyze your communicative activities in lessons?

The essence of the communicative strategy was partially revealed by the students, characterizing this concept as "teacher's action plan" (19\%); "preliminary reflection on communication" (12\%); "planning methods and techniques of communication with students" $(10 \%)$. The answers of other graduates expressed a lack of understanding of the concept: strategy is a "method of working with students" (8\%), "a form of working with students" (6\%); "good attitude to students" (6\%), "understanding of the child" (4\%), "politeness" (3\%). $24 \%$ of graduates could not answer the question.

The students' answers to the second question showed that the dominant qualities of a primary school teacher communicative personality, in their opinion, are "love for children" (32\%), "humanity" $(17 \%)$, "creativity" (16\%), "kindness, patience, fairness, knowledge of the subject" (12\%). Among the priority graduates also named "sociability" (10\%), "honesty, activity, frankness" (7\%). Although in general about $62 \%$ of the teacher characteristics named by graduates are to some extent related to their communicative - strategic competence, such important teacher's communicative qualities as the need for communication, communication strategies and tactics, ability to manage communicative interaction, determine the mental state of the interlocutor, emotional influence on students, ability to achieve a communicative goal and other important qualities were not mentioned. Thus, it can be stated that in the process of future primary school teachers' professional training the concept of language (communicative) personality, its qualities were not clearly formed. A significant part of the qualities mentioned by students (about $40 \%$ ) are not directly related to communication.

To the third question, "Do you plan in advance the way you will communicate with children in class?" $42 \%$ of students answered - yes, 54\% - no, $4 \%$ were undecided. Among the reasons for the necessity for prior planning of communication with students, students pointed to: "the necessity to transfer knowledge and skills to students" (15\%); "to maintain contact with students" (11\%); "to resolve conflict situations in the classroom" (10\%), "to achieve the goal of the lesson" $(8 \%)$; "to use language knowledge in practice" (7\%); "to ensure effective communication with children" (6\%); "to be clear to the interlocutor" (5\%); "to be a role model for students" $(5 \%)$; "to teach students to communicate correctly and competently" (4\%); "to organize interaction between children and teachers" (4\%); "to avoid negative emotions" (3\%); "to use knowledge in practice" $(3 \%)$; "for upbringing of a fully developed child" (3\%); "to identify and take into account individual characteristics and abilities of children" (2\%); "to discover something new and interesting for children" (2\%); "to increase the teacher's efficiency" (2\%); "to develop the ability to understand others" (2\%); "to develop students' motivation to learn the Ukrainian language" (1\%); "to understand the purpose of the conversation" $(1 \%) ;$ "to establish mutual understanding with children" (1\%); "to be able to ask questions correctly and answer them" (1\%); "to use effective interactive methods in their work" (1\%); "to communicate with children and adults using an accessible language" (1\%); "for the ability to easily establish contact with students" (1\%); "to support students, advise, help" (1\%); "to achieve better results in the learning process" (1\%). The analysis of students' answers showed that all the reasons named by them are professionally targeted. At the same time, future teachers who answered "No" or did not answer, apparently, are not fully aware of both personal and professional significance of strategic planning of communication with students.

Regarding the fourth question of the questionnaire, students named the following difficulties in communicating with primary school students: "deficiencies in oral speech (use of russisms, wordparasites, dialectisms, etc.)" (26\%), "inability to establish contact with class and individual students" $(19 \%)$, "difficulties in formulating questions to students during the survey" (15\%), "inability to express oneself correctly when assessing students' answers "(9\%)," inability to resolve conflict situations" (7\%). At the same time, $18 \%$ of students answered that they did not feel any difficulties, $6 \%$ of graduates did not answer the questions. 
Students answered the fifth question as follows: 14\% - "I analyze my communicative behavior in class", 45\% - "sometimes I analyse", 37\% - "I do not analyse", 4\% did not answer the question. Such indicators proved that most graduates have not formed the necessity for reflection of communicative activity.

The analysis of the graduate students' survey data showed that they are not aware of the essence of communicative-strategic competence and communicative strategy. During practice, students mostly use traditional forms and methods of organizing communication with primary school students. Many respondents are not aware of the professional significance of strategic planning of pedagogical communication, as well as the necessity of reflection on communication skills, although they experience many difficulties while communicating with students. More than a third of students rated their level of communication with primary school students as unsatisfactory.

Thus, the results of the questionnaire confirmed the necessity to develop a special methodology of formation of communicative and strategic competence of future primary school teachers.

We offer the technique based on the principles transdisciplinarity. Transdisciplinarity is considered to be a higher level compared to interdisciplinary, which is not limited to interdisciplinary relationships, but analyzes them within the system, with no strict boundaries between disciplines. Articles 5 and 6 of the World Declaration on Higher Education for the 21st Century: Approaches and Practices [15] recommend expanding transdisciplinarity of curricula and developing future professionals' skills to apply this approach to solve complex nature and society problems. Table 1 presents the characteristics of the transdisciplinary methodology for the formation of future primary school teachers' communicative and strategic competence.

\begin{tabular}{|c|c|c|}
\hline № & $\begin{array}{l}\text { Components of the } \\
\text { methodology }\end{array}$ & Content of the components of the methodology \\
\hline 1. & The purpose of training & $\begin{array}{l}\text { Training of a qualified, capable of adapting to professional } \\
\text { conditions, mobile specialist with established communicative } \\
\text { and strategic competence; the future teacher's ability to self- } \\
\text { improvement of communicative qualities }\end{array}$ \\
\hline 2. & $\begin{array}{l}\text { Principles of the } \\
\text { methodology }\end{array}$ & Human values \\
\hline 3. & $\begin{array}{l}\text { The nature of educational } \\
\text { process }\end{array}$ & The process of professional development \\
\hline 4. & $\begin{array}{l}\text { Future teacher's role in } \\
\text { teaching process }\end{array}$ & $\begin{array}{l}\text { An active subject of teaching and creativity, capable of } \\
\text { learning, self-development and reflection }\end{array}$ \\
\hline 5. & $\begin{array}{l}\text { The nature of perceiving of } \\
\text { educational information }\end{array}$ & $\begin{array}{l}\text { Sharing information by means of transdisciplinary } \\
\text { connections, creation of a transdisciplinary field of subjects, } \\
\text { transfer of concepts to other fields of knowledge }\end{array}$ \\
\hline 6. & $\begin{array}{l}\text { The nature of training } \\
\text { activities }\end{array}$ & $\begin{array}{l}\text { Active creative character; nonlinear style of thinking; } \\
\text { excitation of future teachers' own mental forces and abilities; } \\
\text { pluralism of opinions }\end{array}$ \\
\hline 7. & Educational discipline & $\begin{array}{l}\text { Academic discipline - open system, integration of } \\
\text { educational disciplines; introduction of an integrative special } \\
\text { course. "Communicative and strategic competence of } \\
\text { future primary school teachers" }\end{array}$ \\
\hline 8. & Teaching methods & $\begin{array}{l}\text { Various methods and techniques of interactive character } \\
\text { based on students' cognitive activity for developing their } \\
\text { creative abilities }\end{array}$ \\
\hline
\end{tabular}




\begin{tabular}{|l|l|l|}
\hline 9. & Teacher-student interaction & Nonlinear nature of feedback, subject-subject relations \\
\hline 10. & Methodology of teaching & Experimental technique \\
\hline 11. & $\begin{array}{l}\text { The nature of management } \\
\text { of quality professional } \\
\text { training }\end{array}$ & $\begin{array}{l}\text { Indirect management based on partner interaction of } \\
\text { participants in the educational process, co-creation }\end{array}$ \\
\hline
\end{tabular}

Tab. 1. Characteristics of transdisciplinary methods of formation of future primary school teachers' communicative and strategic competence.

The basics of the transdisciplinary method of forming CSC were the following: the student's personality as the center of the educational process; the student is a subject of professional training and takes an active and creative part in the education process; in the course of experimental work freedom of self-expression and self-realization of the future teacher's personality in the educational environment is provided; actualization of the principles of student activity, dialogue, independence, initiative, creativity in learning [13, p. 263].

In the course of experimental work knowledge was not imposed on future teachers, but was acquired by them in the process of teacher-student interaction. We are convinced that only way of promoting of the future teacher's self-development is productive and effective. We also consider the student (youth) age sensitive for the formation of communicative-strategic competence, because at this age young people are open to communication, to the perception of something new, have a natural need for contact with people united around common values, ideals and meanings. Since the linguodidactic concept of "communicative-strategic competence" is interdisciplinary and formed on the basis of integration of research in linguistics, pedagogy, psychology and other sciences, the content of the disciplines of the linguistic and pedagogical cycles was adjusted taking into account the requirements for communicative training of future primary school teachers, kept in domestic and international regulations in the field of education, as well as ensuring of transdisciplinary links.

The basis of the experimental study were the subjects of the linguistic cycle. The core of the experimental methodology was the normative discipline "The Ukrainian language (for professional purposes)", additional disciplines - "Modern Ukrainian language with practical work", "Methods of teaching the Ukrainian language", "Culture and speech technique".

The central pedagogical discipline was "Didactics", additional - "Fundamentals of Pedagogy with basic of the specialty", "Pedagogical skills", "Pedagogical innovation". Transdisciplinary links were implemented to save time, the integration of educational influences empowerment to create communicative spheres and maximize the effectiveness of the process.

The analysis of curricula of the above mentioned disciplines showed that each of them includes some concepts related to the research topic, namely: "linguistic norm", "text", "dialogue", "monologue" ("Modern Ukrainian language with practical work"); "communication", "professional speech", "culture of professional speech", "ethics of business speech", "norms of professional speech", "correctness of professional speech", "tactical means of communication" ("Ukrainian language (for professional purposes)"; "speech technique", "speech logic", "speech expressiveness", "dialogue culture", "text", "types of texts" ("Culture and speech technique"); "communicative-activity approach", "coherent speech", "speech development", "speech activity" ("Methods of teaching the Ukrainian language"); "pedagogical technologies (game, development, development of critical thinking, dialogue, problem-based learning, design, etc.)" ("Pedagogical innovation"), "patterns, principles, forms, methods, techniques, teaching aids", "pedagogical competence of a teacher", "communicative component of pedagogical activity" ("Didactics"); "professional communication", "communicative qualities of a teacher", "styles of pedagogical communication", "barriers and complications of communication", "communicative means", "activity", "pedagogical activity", "types of activity of a teacher", "communication as a kind of activity" ("Fundamentals of Pedagogy with basics of the specialty"); "pedagogical communication", "functions of pedagogical communication", "styles of pedagogical communication", "speech technique" ("Pedagogical skills"). Thus, the content of subjects 
laid the foundation that served to establish transdisciplinary links in the process of forming future teacher' strategic communicative competence. The communicative concepts of navigational nature and the conceptual fields of interconnected communicative concepts to ensure transdisciplinary connections were defined (see Fig. 1). Central concepts of navigational nature (navigation (Latin) - choosing the most profitable way) [4, p. 454] in the study are as follows: "competence", "communicative-strategic competence", "communication", "discourse", "communicative strategy", "communicative tactics".

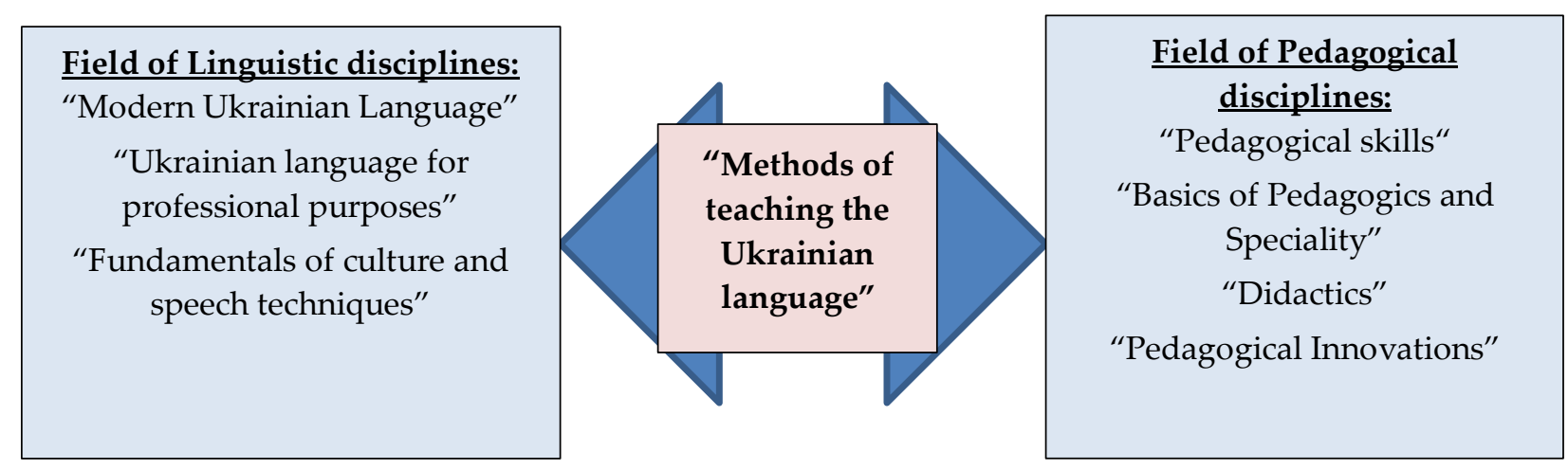

Fig. 1. Scheme of transdisciplinary connections in the process of formation future primary school teachers'communicative and strategic competence.

The development of conceptual fields of transdisciplinary communicative concepts made it possible to:

1) enrich the content of certain academic disciplines, giving them a communicative direction;

2) build a system of formation of future teachers' communicative-strategic competence on the principles of consistency and continuity, avoiding duplication of topics and saving time;

3) ensure a pragmatic practical and professional orientation of linguistic and pedagogical disciplines, as the study of each topic was accompanied by its analysis in terms of application in the process of pedagogical communication.

\begin{tabular}{|c|c|c|c|}
\hline № & Conceptual fields & Topics / Content modules & $\begin{array}{l}\text { Educational disciplines / } \\
\text { semester }\end{array}$ \\
\hline 1. & $\begin{array}{l}\text { Conceptual field } \\
\text { "competence" }\end{array}$ & $\begin{array}{l}\text { The concept of competence and competences. } \\
\text { Key, general and subject competencies. The } \\
\text { teacher's professional and pedagogical } \\
\text { competence, its structure. (Content module } 1 \\
\text { "Pedagogical profession and a teacher's } \\
\text { personality"). }\end{array}$ & $\begin{array}{l}\text { "Fundamentals of pedagogy } \\
\text { with basics of speciality" (1st. } \\
\text { sem.); educational and } \\
\text { introductory practice (2nd } \\
\text { sem.); } \\
\text { "Didactics" (4th sem.) }\end{array}$ \\
\hline 2. & $\begin{array}{l}\text { Conceptual field } \\
\text { "communication" }\end{array}$ & $\begin{array}{l}\text { Communication, its types. } \\
\text { process, its structure. Pedagogical } \\
\text { communication, its functions, types, styles, } \\
\text { means. Communicative situation. The teacher's } \\
\text { communicative personality. The teacher's } \\
\text { communicative qualities. (Content module } 1 \\
\text { "Communication as a tool of professional } \\
\text { activity"). }\end{array}$ & $\begin{array}{l}\text { "The Ukrainian language for } \\
\text { professional purposes" (3rd } \\
\text { sem.); } \\
\text { "Fundamentals of culture } \\
\text { and speech techniques" (2nd } \\
\text { sem.) }\end{array}$ \\
\hline 3. & $\begin{array}{l}\text { Conceptual field } \\
\text { "discourse" }\end{array}$ & $\begin{array}{l}\text { Discourse as a form of communicative } \\
\text { interaction. Genres of pedagogical discourse. } \\
\text { Monological discourse. Dialogic discourse. } \\
\text { (Content module } 2 \text { "Culture of oral professional } \\
\text { communication"). }\end{array}$ & 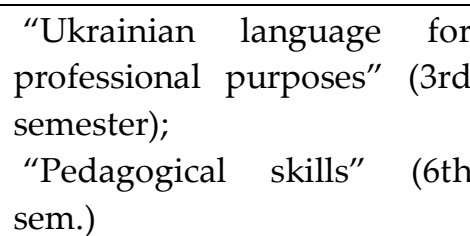 \\
\hline
\end{tabular}




\begin{tabular}{|c|c|c|c|}
\hline 4. & $\begin{array}{l}\text { Conceptual field } \\
\text { "communication } \\
\text { strategy" }\end{array}$ & $\begin{array}{l}\text { Communication strategy. The main types of } \\
\text { pedagogical communication strategies, their } \\
\text { characteristics. Communication tactics as a way } \\
\text { to implement communicative strategies. The } \\
\text { structure of communication strategy and } \\
\text { communication tactics. (Content module } 3 \\
\text { "Professional communication as a component of } \\
\text { a teacher's professional activity"). }\end{array}$ & 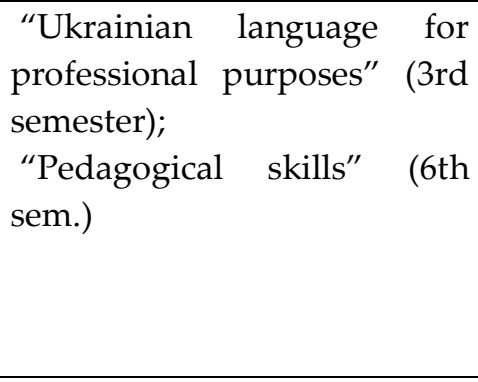 \\
\hline 5. & $\begin{array}{l}\text { Conceptual field } \\
\text { "communicative- } \\
\text { strategic } \\
\text { competence" }\end{array}$ & $\begin{array}{l}\text { Functions of the Ukrainian literary language. } \\
\text { Norms of the Ukrainian literary language as a } \\
\text { basis of the teacher's communicative culture. } \\
\text { (Module } 1 \text { "Introduction"; content module } 2 \\
\text { "Phonetics. Orthoepy. Graphics. Orthography"; } \\
\text { content module } 3 \text { "Lexicology. Phraseology"; } \\
\text { content module } 4 \text { "Word formation. } \\
\text { Morphology"; content module } 5 \text { "Syntax"). } \\
\text { Activity as a factor of personality development. } \\
\text { Communication as a kind of activity. Pedagogical } \\
\text { communication, its functions, types, structure. } \\
\text { Styles of pedagogical communication. The } \\
\text { concept of conflicts, their features. Conflict } \\
\text { situation, components and stages of } \\
\text { development. } \\
\text { Main types of conflicts, their causes. Ways of } \\
\text { resolving conflicts. (Content module } 2 \text { "Modern } \\
\text { system of teacher training". Topic "Professional } \\
\text { communication in the structure of teacher } \\
\text { training"). } \\
\text { Communicative competence of the teacher, its } \\
\text { components. Communicative and strategic } \\
\text { competence of the future primary school teacher, } \\
\text { its content, structure, functions. Communicative } \\
\text { and strategic activity of the teacher. (Content } \\
\text { module } 1 \text { "Communication as a tool of } \\
\text { professional activity"). } \\
\text { Regularities and principles of teaching. Methods, } \\
\text { forms, means of organizing the educational } \\
\text { process. Educational strategies. Educational } \\
\text { technologies. Pedagogical activity of the future } \\
\text { primary school teacher. (Content module } 1 . \\
\text { "Theoretical foundations of Didactics"). } \\
\text { Technologies of formation of communicative- } \\
\text { strategic competence. } \\
\text { Communicative-activity approach as basis of } \\
\text { communicative formation of future primary } \\
\text { school teachers' competence. Subject-subject } \\
\text { communicative interaction with primary school } \\
\text { students. Types of communicative situations in } \\
\text { primary school. Communication problems. }\end{array}$ & $\begin{array}{l}\text { "Modern } \begin{array}{r}\text { Ukrainian } \\
\text { language with practical } \\
\text { work" (2nd -5th sem.) }\end{array} \\
\text { "Fundamentals of } \\
\text { Pedagogics and specialty" } \\
\text { (1st sem.); educational and } \\
\text { introductory practice (2nd } \\
\text { sem.) } \\
\text { "Ukrainian language for } \\
\text { professional purposes" (3rd } \\
\text { sem.) } \\
\text { "Didactics" (4th sem.) }\end{array}$ \\
\hline
\end{tabular}

Tab. 2. Conceptual fields of transdisciplinary communicative concepts in the content of future primary school teachers professional training. 
The implementation of the method of formation of communicative and strategic competence of future teachers was carried out in accordance with the following principles: compliance of the simulated educational process with the ultimate goal of future teachers training in the communicative environment of modern primary school; taking into account specifics of students' future professional activity; taking into account psychological features of future teachers' acquisition of communicative knowledge and skills; optimal combination of theoretical knowledge and practical skills; selection of the most effective forms, methods, technologies of formation of communicative-strategic competence.

Implementation of all components of the methodology of formation of communicative- strategic competence of future primary school teachers is a complex process, the outcome of which depends on a coordinated system of a teacher's activities, teacher-student interaction, as well as future teachers' active attitude. In this regard, the overarching goal of the proposed transdisciplinary methodology was the organization of modern innovative methods and technologies of common communicative-strategic educational environment in the teaching of a certain range of disciplines of linguistic and pedagogical cycles, when the subjects of the educational process are a teacher and students, the object is the content of education. The main way of implementation a communicative approach in the pedagogical practice of future primary school teachers professional training, ensuring discursiveness of communication was the replacement of linear one-way communication "teacher - student" to tripartite communication, i.e. communicative interaction "teacher - student - information". The organization of the training session was considered as an active communicative interaction of teachers and students on a subject-subject basis in a single transdisciplinary information field, when a common professional metalanguage, common pedagogical mentality, and common guidelines for achieving a common goal were used. Talking about the creation of pedagogical discourse, the goal is the process of initial work, ways and methods of acquiring knowledge and skills in a specific intersubjective communicative-dialogic space created by the teacher, whom the student joins as an equal participant of communication with other participants with a common understanding of the social situation, professional world, and professional language. The most important task was to create such an atmosphere in this communicative environment, with frankness, trust, appreciation of every opinion expressed, mutual assistance, security, sincerity. In the process of such inclusion of the future primary school teacher in the relationship with educational information, a teacher and group mates, knowledge was not presented, but acquired by students during interaction in a communicative environment, when future teachers reasoned their opinions, independently sought solutions, acquired necessary professional and universal human qualities.

Because the conceptual apparatus of communicative-strategic competence is a complex hierarchical structure with close internal relationships, it was expected to be gradually mastered by students by moving from one conceptual field of transdisciplinary communicative concepts to another during the educational process. At each stage of the formative experiment, the following methods, techniques, and learning technologies were selected meeting students' learning and cognitive abilities. According to the theory of gradual formation of mental actions (concepts) (Halperin P., Talyzina N.) the following general scheme of assimilation of concepts by students was used: introduction of the context of the problem; analysis of personal communicative experience of future specialists; determining the degree of significance of the problem for students' future professional activity; formation of motivation to acquire new knowledge; students' active participation in mastering knowledge (completing exercises, tasks, solving pedagogical tasks, etc.); analysis of main features of the concept, their specification, clarification, generalization of the main features of the concept in the form of a definition; consolidation of knowledge about the concept; control (self-control) and assessment (self-assessment, mutual assessment) of knowledge; formation of appropriate skills and abilities. Thus, students acquired communicative knowledge and skills mainly by deductive means, which provided enough opportunities for the development of future primary school teachers' critical thinking, the formation of their cognitive activity. 


\section{CONCLUSIONS}

Strategic planning of professional communication in the field of education is necessary for the effective organization and management of the process of teaching and educating students. Its importance is growing in connection with the reform of the education system based on the Concept of the New Ukrainian School. However, the results of the survey of future primary school teachers showed a lack of readiness for professional communication, namely:

1) a significant part of students does not clearly formed the concept of the teacher's communicative personality;

2) most graduate students are not aware of the essence of communication strategies;

3 ) the majority (58\%) of students are not fully aware of both personal and professional importance of strategic planning of communication with students;

4) future teachers do not consider important the reflection of their communicative activities;

5) at the same time, $76 \%$ of graduates experienced some difficulties communicating with students.

Many years of work with students proved, the process of forming the communicative-strategic competence of future teachers is complex and long. The results of this process are as follows:

1) personal traits (positive motivation for communicative activity, professional values, sociability, empathy, tolerance, etc.);

2) students' professional qualities (awareness of the conceptual and terminological apparatus of communicative-strategic competence, genres of pedagogical discourse, ability to analyze the communicative situation, to construct communicative strategies and tactics according to genres of pedagogical discourse and communicative situation, to reflect and self-assess communicative-strategic competence), formed individual style of communication, as well as personal activity and further professional self-improvement).

The successful implementation of these tasks will be achieved by proposed by us transdisciplinary methodology for the formation of communicative-strategic competence, which includes the organization of communicative teacher-student interaction in the process of study a range of linguistic and pedagogical disciplines through dialogue and cooperation using a set of forms, methods, techniques, technologies that provide the opportunity for students to gain experience in solving communicative tasks of various kinds. Thus, the formation of future teachers' communicative-strategic competence is perceived not as imposed, but as one that naturally arises in the process of intersubjective interaction in the new community of subjects in the process of cognition. As a result, the field of higher pedagogical education, like the modern information society, becomes communicative both at the level of goals (informing the student) and as well as at the level of content (providing communicative material) and methods of organization (application of communicatively oriented methods and modern information technologies).

The communicative aspect of professional training of students covers not only the linguistic and pedagogical disciplines mentioned by us, but the whole complex of compulsory and elective disciplines of the specialty "Primary Education". It is impossible to complete professional training of students without using certain communication strategies and tactics. Peculiarities of realization of communicative-strategic approach in the process of teaching disciplines of the educational program "Primary education", the first (bachelor's) degree, which are not specifically aimed at forming students' communicative sphere, will be the subject of our further scientific research. 


\section{REFERENCES}

[1] Andrushchenko V.P., Skubashevska O.S. Language strategies as a factor of educational innovation, 2010. Available at: http://enpuir.npu.edu.ua/bitstream/123456789/14234/1/Andruschenko.pdf. (in Ukrainian)

[2] Arhipova Yu.I., Ignateva E.Yu., Dautova O.B. Educational Communication Strategies In Primary School. European Proceedings of Social and Behavioural Sciences, 87 (2019), 643-649. doi: 10.15405/epsbs.2020.08.02.84

[3] Chiș O., Grec C.D. Pedagogical Aspects of Teaching, Learning, Assessing the Reading-Writing Elements for Primary School. The European Proceedings of Social \& Behavioural Sciences, 18 (2016), 161-166. doi: 10.15405/epsbs. 2016.12.22

[4] Pustovit L.O., Skopnenko O.I., Siuta H.M., Tsymbaliuk T.V. (Eds.) Dictionary of Foreign Words. Dovira, Ridna mova, Kyiv, 2000. (in Ukrainian)

[5] Hrebenshchykova E.H., Kyiashchenko L.P. Transdisciplinary paradigm: science - innovation - society. Edytoryal URSS, Moscow, 2011. (in Russian)

[6] Kyiashchenko L.P. Experience of the philosophy of transdisciplinarity: (case "bioethics"). Questions of philosophy, 8 (2005), 105-117. (in Russian)

[7] Leinonen J., Venninen T. Designing learning experiences together with children. Procedia Social and Behavioural Sciences, 45 (2012), 466-474. doi: 10.1016/j.sbspro.2012.06.583

[8] Liubashenko O.V. Linguodidactic strategies of teaching the Ukrainian language to students of nonspecial faculties of higher educational institutions: author's ref. degree of $\mathrm{PhD}$ : speciality 13.00.02 "Theory and methods of teaching (the Ukrainian language)". Kyiv, 2008. (in Ukrainian)

[9] Wehmeier S. (Ed.) Oxford Advanced Learner Dictionary of Current English. Oxford University Press, 2000.

[10] Plowman Kenneth D., Christopher W. Strategy and tactics in strategic communication: Examining their intersection with social media use. International Journal of Strategic Communication, 12 (2) (2018), 125-144. doi.org/10.1080/1553118X.2018.1428979

[11] Review of the concept of the New Ukrainian school. Available at: us.org.ua/wpcontent/uploads/2017/09/razdel_1_Oglyad.pdf. (in Ukrainian)

[12] Romanenko Yu. Assimilation by students of senior classes of communicative strategies in the process of work with scientific and educational texts of subjects of a humanitarian cycle: dis. of cand. of ped. Science: 13.00.02. Kyiv, 2006. (in Ukrainian)

[13] Slastenyn M. Pedagogical Education. Yzd. dom Mahystr-Press, 2000. (in Russian)

[14] The concept of implementation of the state policy in the field of reforming general secondary education "New Ukrainian School" for the period till 2029. Available at: https://osvita.ua/legislation/Ser_osv/54258/. (in Ukrainian)

[15] UNESCO on the World Conference on Higher Education. Higher Education in the Twenty-First Century: Vision and Action, 1998.

Address: Mariia Oliiar, Kateryna Fomin, Vasyl Stefanyk Precarpathian National University, 57 Shevchenko St., Ivano-Frankivsk 76018, Ukraine.

E-mail: maria oliyar@pnu.edu.ua; kateryna.fomin@pnu.edu.ua.

Received: 15.02.2021; revised: 30.03.2021.

Оліяр Марія, Фомін Катерина. Реалізація трансдисциплінарного підходу в процесі формування комунікативно-стратегічної компетентності майбутніх учителів початкової школи. Журнал Прикарпатського університету імені Василя Стефаника, 8 (1) (2021), 182-192. 
у статті обгрунтовано актуальність проблеми формування комунікативно-стратегічної компетентності майбутніх учителів початкової школи. Наголошено на важливості реалізації комунікативного підходу у фаховій підготовці студентів за умов реформування системи освіти відповідно до Концепції нової української школи. Автори статті підкреслюють специфіку педагогічнго дискурсу як стратегічно спланованого та спрямованого на реалізацію визначеної комунікативної мети. Висвітлено результати анкетування студентів-випускників спеціальності "Початкова освіта", яке підтвердило необхідність розроблення спеціальної методики формування комунікативно-стратегічної компетентності майбутніх педагогів. Розкрито суть трансдисциплінарного підходу як основи означеної методики. Подано характеристику, засадничі положення та наскрізну мету методики. Обгрунтовано, що в умовах організації педагогічного дискурсу метою стає процес начальної роботи, способи і методи здобування знань та засвоєння вмінь у специфічному інтерсуб'єктному комунікативно-діалогічному просторі, створеному викдадачем, до якого студент прилучається як рівноправний учасник комунікації в колі інших учасників зі спільним розумінням соціальної ситуації, специфіки майбутньої професії, фахової мови. Визначено комунікативні поняття навігаційного характеру та схарактеризовано концептуальні поля взаємопов'язаних комунікативних понять для забезпечення трансдисциплінарних зв'язків. Розкрито принципи реалізації запропонованої методики: відповідність змодельованого навчального процесу кінцевій меті підготовки майбутніх педагогів до роботи в умовах комунікативного середовища сучасної початкової школи; урахування специфіки майбутньої професійної діяльності студентів; урахування психологічних особливостей засвоєння майбутніми вчителями комунікативних знань та вмінь; оптимальне поєднання теоретичних знань та практичних умінь студентів; вибір найбільш ефективних форм, методів, технологій формування комунікативно-стратегічної компетентності.

Кдючові слова: майбутній учитель початкової школи, педагогічний дискурс, комунікативна стратегія, комунікативна тактика, комунікативно-стратегічна компетентність, трансдисциплінарність, концептуальне поле комунікативних понять, трансдисциплінарна методика. 